KENOSIS : JURNAL KAJIAN TEOLOGI

ISSN 2460-6901(Print), 2656-4483 (Online)

https://e-journal.iaknambon.ac.id/index.php/KNS

DOI: 10.37196/kenosis.v1i1.234

\title{
MEDIA SOSIAL SEBAGAI SARANA KATEKESE MAHASISWA DI MALANG, JAWA TIMUR
}

\section{Teresia Noiman Derung}

\author{
Sekolah Tinggi Pastoral IPI Malang \\ J1. Seruni No.6, Lowokwaru, Kec. Lowokwaru, \\ Kota Malang, Jawa Timur 65141 \\ teresiaderung@gmail.com
}

\begin{abstract}
This research was conducted to reveal how the use of social media for catechesis activities by the students in Malang City, East Java. This research uses quantitative method. Research subjects are students of religious high schools in Malang, East Java, consisting of 61 people. Data collection using a closed questionnaire using Google Form. The data analysis technique used in this study is scoring, $F$ percent and binomial test. Processing data uses the scoring formula, obtaining an average score of 1.72. This means that in using social media as a means of catechesis, students carry out their involvement well. Based on the results of data processing using the binomial test, the value of $z=4.05$ was obtained. When compared with the table value, this value is lower than the significant level of 0.05, meaning that there is a difference between the involvement of one student and another in using social media as a means of catechesis.
\end{abstract}

Keywords; social media, student, catechesis.

\begin{abstract}
Abstrak
Penelitian ini dilakukan untuk mengungkapkan bagaimana penggunaan media sosial untuk kegiatan katekese oleh para mahasiswa di Kota Malang, Jawa Timur. Penelitian ini menggunakan metode kuantitatif. Subjek penelitian adalah mahasiswa sekolah tinggi agama di Malang, Jawa Timur sebanyak 61 orang. Pengumpulan data menggunakan angket tertutup dengan menggunakan Google Form. Teknik analisis data menggunakan scoring, F prosen dan uji binomial. Pengolahan data menggunakan rumus scoring, memperoleh score rata-rata 1,72. Artinya dalam menggunakan media sosial sebagai sarana katekese, mahasiswa menjalankan keterlibatannya dengan baik. Berdasarkan hasil pengolahan data menggunakan uji binomial diperoleh nilai $z=4,05$. Jika dibandingkan dengan nilai tabel maka nilai tersebut lebih rendah
\end{abstract}


dari taraf signifikan 0,05 artinya ada perbedaan antara keterlibatan mahasiswa yang satu dengan yang lain dalam menggunakan media sosial sebagai sarana katekese.

Kata Kunci; Media sosial; mahasiswa; katekese.

\section{PENDAHULUAN}

Komunikasi digunakan untuk berbagai keperluan. Ada komunikasi yang dilakukan oleh perusahaan untuk kepentingan usahanya. ${ }^{1}$ Ada pula komunikasi yang dilakukan oleh individu untuk berbagai tujuan yang sifatnya personal. Media sosial adalah sarana berkomunikasi sesama pengguna (user) secara personal dan langsung. ${ }^{2}$ Pengguna media sosial dapat berbagi informasi berupa foto, video, animasi, konten, tulisan, dan lain-lain. ${ }^{3}$ Komunikasi melalui sosial media berjalan secara cepat, bahkan realtime. Internet merupakan salah satu aspek penting dalam berhubungan melalui aplikasi media sosial. ${ }^{4}$ Sosial media berkaitan langsung internet yang juga disebut lebih dari sekadar penopang utama manusia untuk berkomunikasi melalui media sosial. 5

Data pengguna media sosial yang paling banyak digunakan di dunia berdasarkan jumlah aktif pengguna adalah Facebook yang mencapai miliaran. Facebook saat ini dikenal sebagai situs media sosial terbesar, dengan lebih dari dua miliar orang menggunakannya setiap bulan. Itu hampir sepertiga dari populasi dunia. ${ }^{6}$ Ada lebih dari 65 juta bisnis menggunakan halaman Facebook dan lebih dari enam juta pengiklan aktif mempromosikan bisnis mereka di Facebook. ${ }^{7}$ Facebook merupakan media sosial yang dimiliki hampir semua orang saat ini. ${ }^{8}$

Selain Facebook, ada WhatsApp yang merupakan aplikasi pengiriman pesan yang biasa orang gunakan untuk media sosial. Awalnya, WhatsApp hanya digunakan untuk berkomunikasi dengan keluarga dan teman-teman. Secara bertahap, orang-orang mulai berkomunikasi untuk keperluan bisnis dan lain-lain. ${ }^{9}$ Ada pula Twitter sebuah aplikasi media yang berbasis microblogging dan memungkinkan pengguna untuk mengunggah tulisan pendek yang dikenal istilah tweet. Para pengguna dapat membuat tweet lalu mem-follow atau mengikuti tweet pengguna lain dengan dukungan aplikasi 
beragam platform dan perangkat. Twitter adalah sarana media sosial untuk berita, hiburan, olahraga, politik, dan banyak lagi. ${ }^{10}$

Jumlah pengguna internet di Indonesia terus meningkat dari waktu ke waktu. Mayoritas warga Indonesia sudah terbiasa menggunakan internet. ${ }^{11}$ Hampir seluruhnya, atau sama dengan 95\% pengguna internet untuk mengakses jejaring sosial. ${ }^{12}$ Situs jejaring sosial yang paling banyak diakses adalah Facebook dan Twitter. ${ }^{13}$ Indonesia menempati peringkat keempat pengguna Facebook terbesar setelah USA, Brazil, dan India. ${ }^{14}$

Pesatnya perkembangan teknologi membuat aplikasi media sosial yang tersambung ke gawai (smartphone). ${ }^{15}$ Semua orang dapat mengakses beberapa situs media sosial yang beragam secara bersamaan. ${ }^{16}$ Di dunia yang serba mudah dan instan ini ada banyak hal yang dapat dieksplorasi dan dipelajari, termasuk dalam penggunaan media sosial dengan berbagai macam fitur serta fasilitas yang ditawarkan, ${ }^{17}$ dan dapat digunakan untuk berbagai macam hal seperti berdagang, belajar, mencari informasi, sharing, dan berdiskusi. ${ }^{18}$

Pada era digital, komunikasi antar pribadi dikembangkan melalui jejaring sosial media. ${ }^{19}$ Media tidak lagi hanya untuk berkomunikasi, tetapi juga berbagi informasi dan pengetahuan. ${ }^{20}$ Jaringan media sosial bisa dibangun melalui kelompok diskusi maya (newsgroup), tulisan di internet (blog-web), video interaktif (video on demand), dan siaran audio (podcasting). ${ }^{21}$ Demikanlah media komunikasi berkembang dengan pesatnya. Media sosial bukan hanya sekadar pelengkap kehidupan, tetap telah menjadi kebutuhan tersendiri. ${ }^{22}$ Itu sebabnya, sehari tanpa bermedia sosial seperti ada yang kurang, terutama bagi generasi milenial. ${ }^{23}$

Hidup umat beriman di era digital ini juga tidak lepas dari pengaruh budaya digital yang mewarnai hidup umat beriman. Melalui media sosial umat beriman perlu cerdas dan bijak menemukan dan mendengarkan Tuhan yang bersabda di tengah kehidupan. ${ }^{24}$ Penggunaan media sosial sebagai sarana katekese harus dimulai dari para pelaku katekese itu sendiri karena hal tersebut sangat relevan dan dibutuhkan Gereja dalam situasi saat ini. ${ }^{25}$

Era media sosial menimbulkan istilah baru seperti "katekese online". Katekese online bisa dilakukan dengan memanfaatkan media sosial. Katekese perlu menggunakan media digital sebagai peleburan antara penggunaan media komunikasi 
dengan prinsip pendidikan iman. Proses katekese mampu dioptimalkan melalui segala perangkat, termasuk media sosial. ${ }^{26}$ Katekis diharap mengoptimalkan fasilitas media sosial untuk mendukung proses katekese. Katekis dapat melakukan proses katekese melalui media sosial. Katekis dapat memanfaatkan media sosial untuk kepentingan multifungsi, dari visualisasi, narasi, pengantar, peneguh, sumber pendalaman atau sebagai hiburan. $^{27}$

Maka katekese dapat lebih fleksibel dilakukan pada era media sosial, dengan berkomunikasi lewat media sosial yang tidak dibatasi tempat dan waktu. Pelaksanaan katekese yang berlangsung selama ini, lebih formal dan terbatas waktu dan tempat. Sehingga pelaksanaannya juga memiliki keterbatasan. Padahal bagi mereka yang sudah dibaptis diperlukan penguatan dalam pengajaran dan pendalaman keimanan kepada mereka. Hal ini memungkinkan terjadinya komunikasi lebih intens, terutama bagi para mahasiswa yang tidak terlalu menyukai hal-hal yang bersifat formal.

Proses interaksi melalui media sosial menjadi media proses penguatan katekese. Melalui proses interaktif, terjadi upaya untuk berbagi pengalaman dan pengetahuan iman yang bisa saling meneguhkan dan mengembangkan. Penelitian ini berupaya untuk mengungkap bagaimana penggunaan media sosial oleh para mahasiswa sekolah tinggi agama di Malang Jawa Timur untuk kegiatan katekese. Katakese merupakan pengajaran, pendalaman, dan pendidikan iman agar seorang Kristen semakin dewasa dalam iman, diperuntukkan bagi orang-orang yang sudah dibaptis di tengah umat Kristen

\section{METODE PENELITIAN}

Penelitian ini menggunakan metode kuantitatif deskriptif. Responden dalam penelitian ini sebanyak 61 orang mahasiswa di Kota Malang, Jawa Timur. Pemilihan responden dilakukan dengan teknik random sampling, setiap orang mendapat kesempatan yang sama sebagai sampel berdasarkan penentuan interval, dengan rumus $\mathrm{I}=\frac{N}{n}$. I merupakan interval, $\mathrm{N}$ adalah populasi, dan $\mathrm{n}$ adalah responden yang dipilih secara acak. Berdasarkan rumus ini, peneliti memperoleh interval kelipatan 4 yaitu 4 , 8,12 , dan seterusnya berdasarkan nomor urut sampai 240 orang.

Lokasi penelitian dilakukan di Kota Malang, Jawa Timur terhadap mahasiswa yang terlibat menggunakan media sosial sebagai sarana katekese Kota Malang dipilih 
karena mahasiswa memiliki program untuk menggunakan media sosial sebagai sarana katekese. Variabel penelitian ini merupakan variabel tunggal yaitu keterlibatan mahasiswa dalam penggunaan media sosial sebagai sarana katekese. Teknik pengumpulan data menggunakan angket tertutup yang berisi instrumen penelitian yang terdiri dari sub variabel, yaitu: 1) keterlibatan, 2) sarana katekese, dan 3) faktor pendukung dan penghambat. Keterlibatan meliputi keterlibatan aktif (enduring involvement) dan keterlibatan pasif (situasional involvment).

Teknik analisis data awalnya menggunakan rumus skoring untuk memberi skor atau nilai dari angket yang telah diisi secara tertutup oleh responden. Ketika responden menjawab "ya" skor yang didapat adalah 2, dan ketika menjawab "tidak" maka skornya 1. Berikut ini grafis skoring berdasarkan sub variabel, dengan jumlah N 61 orang.

Tabel 1.

Berdasarkan Rumus Skoring Responden (Sumber: Diolah oleh peneliti, 2020).

\begin{tabular}{|c|c|c|}
\hline \multirow{2}{*}{ Sub Variabel } & \multicolumn{2}{|c|}{ Scoring } \\
\cline { 2 - 3 } & $\begin{array}{c}\text { Ya } \\
\text { (A) }\end{array}$ & $\begin{array}{c}\text { Tidak } \\
\text { (B) }\end{array}$ \\
\hline Keterlibatan Aktif & 21,04 & 5,47 \\
\hline Keterlibatan Pasif & 5,14 & 1,42 \\
\hline Perangkat & 5,80 & 0,09 \\
\hline Media Sosial & 6,29 & 0,85 \\
\hline Faktor pendukung & 7,27 & 0,36 \\
\hline Faktor & 3,73 & 1,13 \\
\hline Penghambat & 49,31 & 9,34 \\
\hline Jumlah & \multicolumn{2}{|c|}{58,65} \\
\hline \multirow{2}{*}{ Skor Rata-Rata } & \multicolumn{2}{|c|}{1,72} \\
\cline { 2 - 3 }
\end{tabular}

Peneliti menyajikan hasil setiap sub variabel secara keseluruhan berdasarkan rumus binomial, yaitu $Z=\frac{(x \pm 0,5)-\mathrm{NP}}{\sqrt{\mathrm{NPQ}}}$. 
Tabel 2.

Berdasarkan Rumus Binomial (Sumber: Diolah Peneliti, 2020)

\begin{tabular}{|l|c|c|c|c|c|}
\hline \multirow{2}{*}{ Sub Variabel } & \multicolumn{4}{|c|}{ Binomial } & \multirow{2}{*}{ Total } \\
\cline { 2 - 5 } & A & Z & B & Z & \\
\hline $\begin{array}{l}\text { Keterlibatan } \\
\text { Aktif }\end{array}$ & 40,12 & 2,40 & 20,87 & $-2,40$ & 61 \\
\hline Keterlibatan Pasif & 39,25 & 2,17 & 21,75 & $-2,17$ & 61 \\
\hline Perangkat & 59 & 7,17 & 2 & $-7,17$ & 61 \\
\hline Media Sosial & 48 & 4,41 & 13 & $-4,41$ & 61 \\
\hline $\begin{array}{l}\text { Faktor } \\
\text { pendukung }\end{array}$ & 55,5 & 6,27 & 5,5 & $-6,27$ & 61 \\
\hline $\begin{array}{l}\text { Faktor } \\
\text { Penghambat }\end{array}$ & 38 & 1,87 & 23 & $-1,87$ & 61 \\
\hline Jumlah & 279,87 & 24,31 & 86,12 & $-24,31$ & 366 \\
\hline Rata-Rata & 46,64 & 4,05 & 14,35 & $-4,05$ & 61 \\
\hline
\end{tabular}

Tabel 3.

Data Scoring Bidang I Perangkat (Sumber: Diolah Peneliti, 2020).

\begin{tabular}{|c|c|c|c|c|}
\hline & & & & N=61 \\
\hline \multirow{2}{*}{ No Bidang } & \multirow{2}{*}{ No Item } & \multicolumn{2}{|c|}{ Jumlah } & \multirow{2}{*}{ Total } \\
\cline { 3 - 5 } & & A & B & \\
\hline \multirow{2}{*}{ I } & 1 & 61 & 0 & 61 \\
\hline & 2 & 59 & 2 & 61 \\
\hline \multicolumn{2}{|c|}{ Jumlah } & 57 & 4 & 61 \\
\hline \multicolumn{2}{|c|}{ Rata-Rata Scoring } & 5,80 & 0,09 & 5,90 \\
\cline { 2 - 5 } & & & 1,96 \\
\hline
\end{tabular}


Tabel 4.

Data Scoring Bidang II Media Sosial (Sumber: Diolah Peneliti, 2020).

\begin{tabular}{|c|c|c|c|c|}
\hline & & & & N=61 \\
\hline \multirow{2}{*}{ No Bidang } & \multirow{2}{*}{ No Item } & \multicolumn{2}{|c|}{ Jumlah } & \multirow{2}{*}{ Total } \\
\cline { 3 - 5 } & & $\mathrm{A}$ & $\mathrm{B}$ & \\
\hline & 4 & 54 & 7 & 61 \\
\hline II & 5 & 61 & 0 & 61 \\
\hline & 6 & 57 & 4 & 61 \\
\hline \multicolumn{2}{|c|}{ Jumlah } & 20 & 41 & 61 \\
\hline \multicolumn{2}{|c|}{ Rata-Rata Scoring } & 6,29 & 0,85 & 7,14 \\
\cline { 3 - 5 } & 7 & & & 1,78 \\
\hline
\end{tabular}

Tabel 5.

Data Scoring Bidang III Keterlibatan Aktif (Sumber: Diolah Peneliti, 2020).

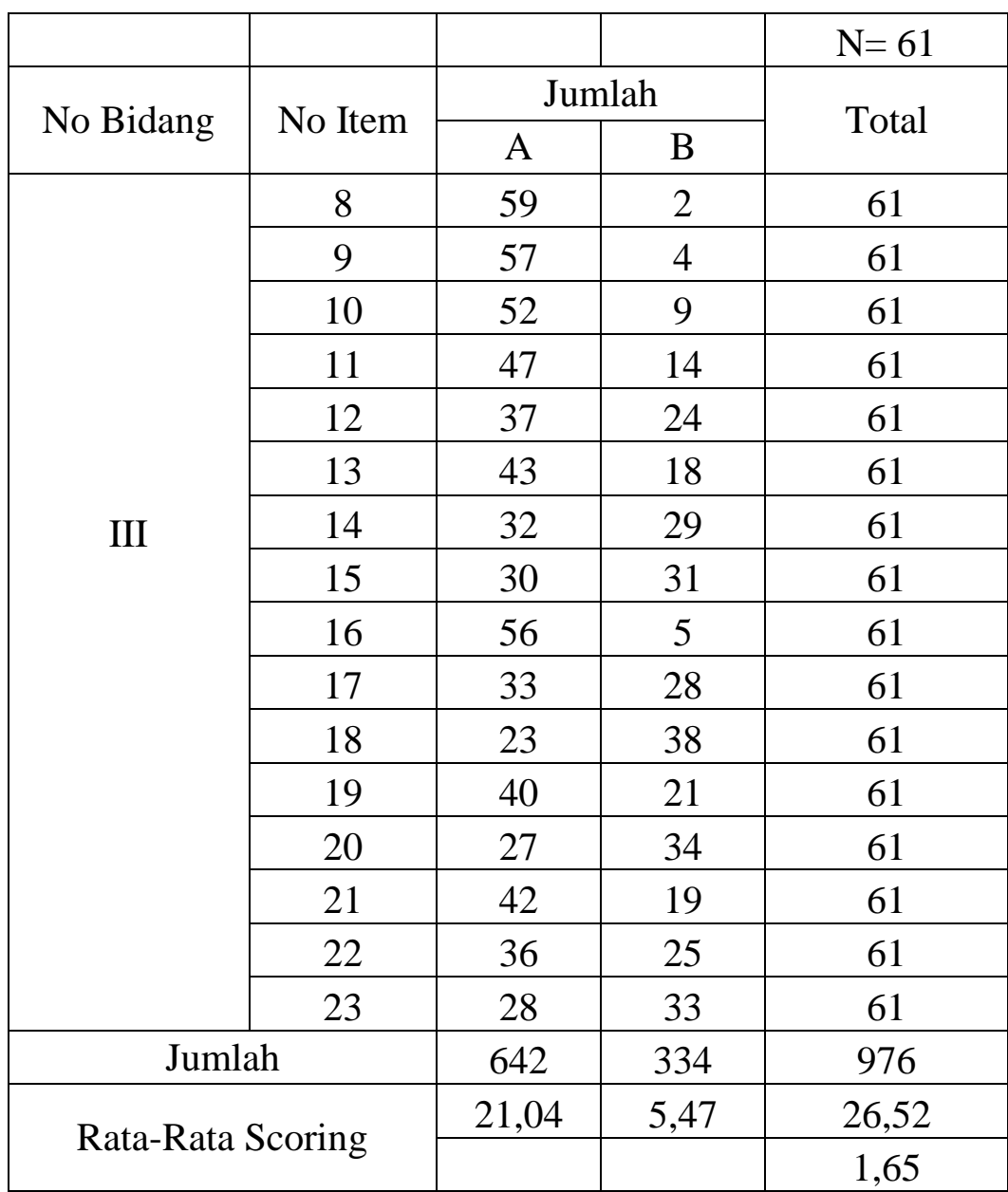


Tabel 6.

Data Scoring Bidang IV Keterlibatan Pasif (Sumber: Diolah Peneliti, 2020).

\begin{tabular}{|c|c|c|c|c|}
\hline & & & & \multirow{2}{*}{ N=61 } \\
\hline \multirow{2}{*}{ No Bidang } & \multirow{2}{*}{ No Item } & \multicolumn{2}{|c|}{ Jumlah } & \multirow{2}{*}{ Total } \\
\cline { 3 - 5 } & & $\mathrm{A}$ & $\mathrm{B}$ & \\
\hline \multirow{3}{*}{ IV } & 24 & 23 & 38 & 61 \\
\cline { 2 - 5 } & 25 & 55 & 6 & 61 \\
\cline { 2 - 5 } & 26 & 45 & 16 & 61 \\
\cline { 2 - 5 } & 27 & 34 & 27 & 61 \\
\hline \multicolumn{2}{|c|}{ Jumlah } & 157 & 87 & 244 \\
\hline \multicolumn{2}{|c|}{ Rata-Rata Scoring } & 5,14 & 1,42 & 6,57 \\
\cline { 2 - 5 } & & & 1,64 \\
\hline
\end{tabular}

Tabel 7.

Data Keseluruhan Scoring (Sumber: Diolah Peneliti, 2020).

\begin{tabular}{|c|c|c|c|}
\hline & & & $\mathrm{N}=61$ \\
\hline \multirow{2}{*}{ No Bidang } & \multirow{2}{*}{ No Item } & \multicolumn{2}{|c|}{ Scoring } \\
\cline { 3 - 4 } & & $\mathrm{A}$ & $\mathrm{B}$ \\
\hline I & $1-3$ & 5,80 & 0,09 \\
\hline II & $4-7$ & 6,29 & 0,85 \\
\hline III & $8-23$ & 21,04 & 5,47 \\
\hline IV & $24-27$ & 5,14 & 1,42 \\
\hline V & $28-31$ & 7,27 & 0,36 \\
\hline VI & $32-34$ & 3,73 & 1,13 \\
\hline \multicolumn{2}{|c|}{ Jumlah } & 49,31 & 9,34 \\
\hline \multirow{2}{*}{ Skor Rata-Rata } & \multicolumn{3}{|c|}{58,65} \\
\cline { 2 - 4 } &
\end{tabular}

Tabel 8.

Data Binomial Keseluruhan (Sumber: Diolah Peneliti, 2020).

\begin{tabular}{|c|c|c|c|c|c|c|}
\hline & & & & & & $\mathrm{N}=61$ \\
\hline \multirow{2}{*}{ No Bidang } & \multirow{2}{*}{ No Item } & \multicolumn{4}{|c|}{ Binomial } & \multirow{2}{*}{ Total } \\
\hline & & A & $\mathrm{Z}$ & $\mathrm{B}$ & $\mathrm{Z}$ & \\
\hline $\mathrm{I}$ & $1-3$ & 59 & 7,17 & 2 & $-7,17$ & 61 \\
\hline II & $4-7$ & 48 & 4,41 & 13 & $-4,41$ & 61 \\
\hline III & $8--23$ & 40,12 & 2,40 & 20,87 & $-2,40$ & 61 \\
\hline
\end{tabular}




\begin{tabular}{|c|c|c|c|c|c|c|}
\hline IV & $24-27$ & 39,25 & 2,17 & 21,75 & $-2,17$ & 61 \\
\hline V & $28-31$ & 55,5 & 6,27 & 5,5 & $-6,27$ & 61 \\
\hline VI & $32-34$ & 38 & 1,87 & 23 & $-1,87$ & 61 \\
\hline \multicolumn{2}{|c|}{ Jumlah } & 279,87 & 24,31 & 86,12 & $-24,31$ & 366 \\
\hline \multicolumn{2}{|c|}{ Rata-Rata } & 46,64 & 4,05 & 14,35 & $-4,05$ & 61 \\
\hline
\end{tabular}

Hipotesis yang diajukan dalam penelitian ini adalah:

$\mathrm{H}_{0}$ : Tidak ada perbedaan antara mahasiswa yang terlibat ataupun yang tidak terlibat

$\mathrm{H}_{\mathrm{a}}$ : Mahasiswa di Kota Malang sudah menggunakan media sosial sebagai sarana katekese

Untuk menguji hipotesis tersebut, peneliti menggunakan uji binomial dengan rumus sebagai berikut:

$$
Z=\frac{(x \pm 0,5)-\mathrm{NP}}{\sqrt{\mathrm{NPQ}}}
$$

Dari Hasil penghitungan dengan rumus binomial, maka hasil yang diperoleh adalah $z=4,05$. Jika dibandingkan dengan nilai tabel, maka nilai tersebut lebih rendah dari taraf signifikan 0,05.Jadi dalam hal ini ada perbedaan yang signifikan antara keterlibatan mahasiswa yang satu dengan mahasiswa yang lain dalam penggunaan media sosial sebagai sarana katekese, maka Hipotesis $\mathrm{Nol}\left(\mathrm{H}_{0}\right)$ ditolak dan Hipotesis Alternatif $\left(\mathrm{H}_{\mathrm{a}}\right)$ diterima.

\section{HASIL DAN PEMBAHASAN}

Dari hasil penelitian tentang mahasiswa yang memiliki perangkat, handphone/ laptop yang mendukung untuk mengakses media sosial diperoleh data berikut. Sebanyak 61 responden $(100 \%)$ memiliki perangkat (handphone/laptop) yang mendukung untuk mengakses media sosial. Sebanyak 0 responden $(0 \%)$ tidak memiliki perangkat (handphone/ laptop) yang mendukung untuk mengakses media sosial. Dari hasil pengolahan data menggunakan scoring diperoleh nilai rata-rata dua artinya dalam hal ini mahasiswa sudah baik. Dari pengolahan menggunakan binomial diperoleh nilai z: 7,68 jika dibandingkan dengan nilai tabel maka nilai tersebut lebih 
rendah dari taraf signifikan 0,05. Jadi ada perbedaan yang signifikan dengan tendensi pada yang terlibat.

Dari hasil penelitian tentang mahasiswa yang mampu mengoperasikan perangkat yang mendukung untuk mengakses media sosial diperoleh data berikut. Sebanyak 59 responden $(96,72 \%)$ mampu mengoperasikan perangkat yang mendukung untuk mengakses media sosial. Sebanyak 2 responden $(3,27 \%)$ tidak mampu mengoperasikan perangkat yang mendukung untuk mengakses media sosial. Dari hasil pengolahan data menggunakan scoring diperoleh nilai rata-rata 1,96 artinya dalam hal ini kemampuan mahasiswa mengoperasikan perangkat pendukung sudah baik. Dari pengolahan menggunakan binomial diperoleh nilai z: 7,17 jika dibandingkan dengan nilai tabel maka nilai tersebut lebih rendah dari taraf signifikan 0,05. Jadi ada perbedaan yang signifikan dengan tendensi pada yang terlibat. Artinya antara mahasiswa yang mampu mengoperasikan perangkat dan mahasiswa yang tidak mampu mengoperasikan perangkat terdapat perbedaan yang signifikan dengan tendensi pada yang terlibat karena nilai A lebih besar dari nilai B.

Dari hasil penelitian tentang mahasiswa yang merupakan pengguna aktif media sosial diperoleh data berikut. Sebanyak 54 responden $(88,52 \%)$ merupakan pengguna aktif media sosial dan 7 responden $(11,47 \%)$ bukan merupakan pengguna aktif media sosial. Dari hasil pengolahan data menggunakan scoring diperoleh nilai rata-rata 1,88 artinya dalam hal ini mahasiswa sudah baik. Dari pengolahan menggunakan binomial diperoleh nilai z: 5,88 jika dibandingkan dengan nilai tabel maka nilai tersebut lebih rendah dari taraf signifikan 0,05. Jadi ada perbedaan yang signifikan dengan tendensi pada yang terlibat. Artinya antara mahasiswa yang merupakan pengguna aktif media sosial dan mahasiswa yang tidak merupakan pengguna aktif media sosial terdapat perbedaan yang signifikan dengan tendensi pada yang terlibat karena nilai A lebih besar dari nilai B.

Dari hasil penelitian tentang mahasiswa yang memiliki akun Whatsapp diperoleh data berikut. Sebanyak 61 responden (100\%) memiliki akun Whatsapp dan 0 responden $0 \%$ tidak memiliki akun Whatsapp. Dari hasil pengolahan data menggunakan scoring diperoleh nilai rata-rata 2, artinya dalam hal ini mahasiswa sudah baik. Dari pengolahan menggunakan binomial diperoleh nilai z: 7,68 jika 
dibandingkan dengan nilai tabel maka nilai tersebut lebih rendah dari taraf signifikan 0,05 .

Dari hasil penelitian tentang mahasiswa yang memiliki akun Facebook diperoleh data berikut. Sebanyak 57 responden $(93,44 \%)$ memiliki akun Facebook dan 4 responden (6,55\%) tidak memiliki akun Facebook. Dari hasil pengolahan data menggunakan scoring diperoleh nilai rata-rata 1,93 artinya dalam hal ini mahasiswa sudah baik. Dari pengolahan menggunakan binomial diperoleh nilai z: 6,65 jika dibandingkan dengan nilai tabel maka nilai tersebut lebih rendah dari taraf signifikan 0,05. Jadi ada perbedaan yang signifikan dengan tendensi pada yang terlibat. Artinya antara mahasiswa yang memiliki akun Facebook dan mahasiswa yang tidak memiliki akun Facebook terdapat perbedaan yang signifikan dengan tendensi pada yang terlibat karena nilai A lebih besar dari nilai B.

Dari hasil penelitian tentang mahasiswa yang memiliki akun Twitter diperoleh data berikut. Sebanyak 20 responden (32,78\%) memiliki akun Twitter. Sebanyak 41 responden $(67,21 \%)$ tidak memiliki akun Twitter. Dari hasil pengolahan data menggunakan scoring diperoleh nilai rata-rata 1,32 artinya dalam hal ini mahasiswa tidak baik. Dari pengolahan menggunakan binomial diperoleh nilai z: 2,56 jika dibandingkan dengan nilai tabel maka nilai tersebut lebih rendah dari taraf signifikan 0,05. Jadi ada perbedaan yang signifikan dengan tendensi pada yang tidak terlibat. Artinya antara mahasiswa yang memiliki akun Twitter dan mahasiswa yang tidak memiliki akun Twitter terdapat perbedaan yang signifikan dengan tendensi pada yang terlibat karena nilai B lebih besar dari nilai A.

Dari hasil penelitian tentang mahasiswa yang tertarik menggunakan media sosial sebagai sarana katekese, diperoleh data berikut. Sebanyak 59 responden $(96,72 \%)$ tertarik menggunakan media sosial sebagai sarana katekese. Sebanyak 2 responden $(3,27 \%)$ tidak tertarik menggunakan media sosial sebagai sarana katekese. Dari hasil pengolahan data menggunakan scoring diperoleh nilai rata-rata 1,96 artinya dalam hal ini mahasiswa sudah baik. Dari pengolahan menggunakan binomial diperoleh nilai z: 7,17 jika dibandingkan dengan nilai tabel maka nilai tersebut lebih rendah dari taraf signifikan 0,05. Jadi ada perbedaan yang signifikan dengan tendensi pada yang terlibat. Artinya antara mahasiswa yang tertarik menggunakan media sosial sebagai sarana katekese dan mahasiswa yang tidak tertarik menggunakan media sosial 
sebagai sarana katekese terdapat perbedaan yang signifikan dengan tendensi pada yang terlibat karena nilai A lebih besar dari nilai B.

Dari hasil penelitian tentang mahasiswa yang pernah menggunakan media sosial sebagai sarana katekese, diperoleh data berikut. Sebanyak 57 responden $(93,44 \%)$ pernah menggunakan media sosial sebagai sarana katekese. Sebanyak 4 responden $(6,55 \%)$ tidak pernah menggunakan media sosial sebagai sarana katekese. Dari hasil pengolahan data menggunakan scoring diperoleh nilai rata-rata 1,93 artinya dalam hal ini mahasiswa sudah baik. Dari pengolahan menggunakan binomial diperoleh nilai z: 6,65 jika dibandingkan dengan nilai tabel maka nilai tersebut lebih rendah dari taraf signifikan 0,05 . Jadi ada perbedaan yang signifikan dengan tendensi pada yang terlibat. Artinya antara mahasiswa yang pernah menggunakan media sosial sebagai sarana katekese dan mahasiswa yang tidak pernah menggunakan media sosial sebagai sarana katekese terdapat perbedaan yang signifikan dengan tendensi pada yang terlibat karena nilai A lebih besar dari nilai B.

Dari hasil penelitian tentang mahasiswa yang merasa memiliki tanggung jawab untuk menggunakan media sosial sebagai sarana katekese diperoleh data berikut. Sebanyak 52 responden $(85,24 \%)$ merasa memiliki tanggung jawab untuk menggunakan media sosial sebagai sarana katekese. Sebanyak 9 responden $(14,75 \%)$ tidak merasa memiliki tanggung jawab untuk menggunakan media sosial sebagai sarana katekese. Dari hasil pengolahan data menggunakan scoring diperoleh nilai ratarata 1,85 artinya dalam hal ini mahasiswa sudah baik. Dari pengolahan menggunakan binomial diperoleh nilai z: 5,37 jika dibandingkan dengan nilai tabel maka nilai tersebut lebih rendah dari taraf signifikan 0,05. Jadi ada perbedaan yang signifikan dengan tendensi pada yang terlibat. Artinya antara mahasiswa yang merasa memiliki tanggung jawab untuk menggunakan media sosial sebagai sarana katekese dan mahasiswa yang tidak merasa memiliki tanggung jawab untuk menggunakan media sosial sebagai sarana katekese terdapat perbedaan yang signifikan dengan tendensi pada yang terlibat karena nilai A lebih besar dari nilai B.

Dari hasil penelitian tentang mahasiswa yang membagikan katekese di media sosial berupa tulisan diperoleh data berikut. Sebanyak 47 responden $(77,04 \%)$ membagikan katekese di media sosial berupa tulisan. Sebanyak 14 responden $(22,95 \%)$ tidak membagikan katekese di media sosial berupa tulisan. Dari hasil 
pengolahan data menggunakan scoring diperoleh nilai rata-rata 1,77 artinya dalam hal ini mahasiswa sudah baik. Dari pengolahan menggunakan binomial diperoleh nilai z: 4,09 jika dibandingkan dengan nilai tabel maka nilai tersebut lebih rendah dari taraf signifikan 0,05. Jadi ada perbedaan yang signifikan dengan tendensi pada yang terlibat. Artinya antara mahasiswa yang membagikan katekese di media sosial berupa tulisan dan mahasiswa yang tidak membagikan katekese di media sosial berupa tulisan terdapat perbedaan yang signifikan dengan tendensi pada yang terlibat karena nilai $\mathrm{A}$ lebih besar dari nilai B.

Dari hasil penelitian tentang mahasiswa yang membagikan katekese di media sosial berupa gambar diperoleh data berikut. Sebanyak 37 responden $(60,65 \%)$ membagikan katekese di media sosial berupa gambar. Sebanyak 24 responden $(39,34 \%)$ tidak membagikan katekese di media sosial berupa gambar. Dari hasil pengolahan data menggunakan scoring diperoleh nilai rata-rata 1,60 artinya dalam hal ini mahasiswa sudah baik. Dari pengolahan menggunakan binomial diperoleh nilai z: 1,53 jika dibandingkan dengan nilai tabel maka nilai tersebut lebih tinggi dari taraf signifikan 0,05. Jadi tidak ada perbedaan yang signifikan. Artinya antara mahasiswa yang membagikan katekese di media sosial berupa gambar dan mahasiswa yang tidak membagikan katekese di media sosial berupa gambar tidak terdapat perbedaan yang signifikan.

Dari hasil penelitian tentang mahasiswa yang membagikan katekese di media sosial berupa tulisan dan gambar diperoleh data berikut. Sebanyak 43 responden $(70,49 \%)$ membagikan katekese di media sosial berupa tulisan dan gambar. Sebanyak 18 responden $(29,50 \%)$ tidak membagikan katekese di media sosial berupa tulisan dan gambar. Dari hasil pengolahan data menggunakan scoring diperoleh nilai rata-rata 1,70 artinya dalam hal ini mahasiswa sudah baik. Dari pengolahan menggunakan binomial diperoleh nilai z: 3,07 jika dibandingkan dengan nilai tabel maka nilai tersebut lebih rendah dari taraf signifikan 0,05. Jadi ada perbedaan yang signifikan dengan tendensi pada yang terlibat. Artinya antara mahasiswa yang membagikan katekese di media sosial berupa tulisan dan gambar dan mahasiswa yang tidak membagikan katekese di media sosial berupa tulisan dan gambar terdapat perbedaan yang signifikan dengan tendensi pada yang terlibat karena nilai A lebih besar dari nilai B. 
Dari hasil penelitian tentang mahasiswa yang membagikan katekese di media sosial berupa video,diperoleh data berikut. Sebanyak 32 responden $(52,45 \%)$ membagikan katekese di media sosial berupa video. Sebanyak 29 responden (47,54\%) tidak membagikan katekese di media sosial berupa video. Dari hasil pengolahan data menggunakan scoring diperoleh nilai rata-rata 1,52 artinya dalam hal ini mahasiswa sudah baik. Dari pengolahan menggunakan binomial diperoleh nilai z: 0,25 jika dibandingkan dengan nilai tabel maka nilai tersebut lebih rendah dari taraf signifikan 0,05. Jadi tidak ada perbedaan yang signifikan dengan tendensi pada yang terlibat. Artinya antara mahasiswa yang membagikan katekese di media sosial berupa video dan mahasiswa yang tidak membagikan katekese di media sosial berupa video tidak terdapat perbedaan yang signifikan.

Dari hasil penelitian tentang mahasiswa yang membuat persiapan materi pribadi sebelum memberikan katekese melalui media sosial, diperoleh data berikut. Sebanyak 30 responden $(49,18 \%)$ membuat persiapan materi pribadi sebelum memberikan katekese melalui media sosial. Sebanyak 31 responden $(50,81 \%)$ tidak membuat persiapan materi pribadi sebelum memberikan katekese melalui media sosial. Dari hasil pengolahan data menggunakan scoring diperoleh nilai rata-rata 1,49 artinya dalam hal ini mahasiswa tidak baik. Dari pengolahan menggunakan binomial diperoleh nilai z: 0 jika dibandingkan dengan nilai tabel maka nilai tersebut lebih rendah dari taraf signifikan 0,05 . Jadi tidak ada perbedaan yang signifikan dengan tendensi pada yang terlibat. Artinya antara mahasiswa yang membuat persiapan materi pribadi sebelum memberikan katekese melalui media sosial dan mahasiswa yang tidak membuat persiapan materi pribadi sebelum memberikan katekese melalui media sosial tidak terdapat perbedaan yang signifikan.

Dari hasil penelitian tentang mahasiswa yang pernah menerima katekese dari media sosial dan membagikannya kembali diperoleh data berikut. Sebanyak 56 responden $(91,8 \%)$ pernah menerima katekese dari media sosial dan membagikannya kembali. Sebanyak 5 responden $(8,19 \%)$ tidak pernah menerima katekese dari media sosial dan membagikannya kembali. Dari hasil pengolahan data menggunakan scoring diperoleh nilai rata-rata 1,91 artinya dalam hal ini mahasiswa sudah baik. Dari pengolahan menggunakan binomial diperoleh nilai z: 6,40 jika dibandingkan dengan nilai tabel maka nilai tersebut lebih rendah dari taraf signifikan 0,05. Jadi ada 
perbedaan yang signifikan dengan tendensi pada yang terlibat. Artinya antara mahasiswa yang pernah menerima katekese dari media sosial dan membagikannya kembali dan mahasiswa yang tidak pernah menerima katekese dari media sosial dan membagikannya terdapat perbedaan yang signifikan dengan tendensi pada yang terlibat karena nilai A lebih besar dari nilai B.

Dari hasil penelitian tentang mahasiswa yang pernah menerima katekese dari media sosial lalu menyuntingnya kemudian membagikan kembali dari hasil penelitian diperoleh data berikut. Sebanyak 33 responden (54,09\%) pernah menerima katekese dari media sosial lalu menyuntingnya kemudian membagikan kembali. Sebanyak 28 responden $(45,90 \%)$ tidak pernah menerima katekese dari media sosial lalu menyuntingnya kemudian membagikan kembali. Dari hasil pengolahan data menggunakan scoring diperoleh nilai rata-rata 1,54 artinya dalam hal ini mahasiswa sudah baik. Dari pengolahan menggunakan binomial diperoleh nilai z: 0,51 jika dibandingkan dengan nilai tabel maka nilai tersebut lebih rendah dari taraf signifikan 0,05. Jadi tidak ada perbedaan yang signifikan dengan tendensi pada yang terlibat. Artinya antara mahasiswa yang pernah menerima katekese dari media sosial lalu menyuntingnya kemudian membagikan kembali dan mahasiswa yang tidak pernah menerima katekese dari media sosial lalu menyuntingnya kemudian membagikan kembali tidak terdapat perbedaan yang signifikan.

Dari hasil penelitian tentang mahasiswa yang bertitik tolak dari terang Injil dan ajaran Gereja dalam memberikan katekese melalui media sosial secara konsisten diperoleh data berikut. Sebanyak 40 responden $(65,57 \%)$ bertitik tolak dari terang Injil dan ajaran Gereja dalam memberikan katekese melalui media sosial secara konsisten. Sebanyak 21 responden $(34,42 \%)$ tidak bertitik tolak dari terang Injil dan ajaran Gereja dalam memberikan katekese melalui media sosial secara konsisten. Dari hasil pengolahan data menggunakan scoring diperoleh nilai rata-rata 1,65 artinya dalam hal ini mahasiswa sudah baik. Dari pengolahan menggunakan binomial diperoleh nilai z: 2,3 jika dibandingkan dengan nilai tabel maka nilai tersebut lebih rendah dari taraf signifikan 0,05. Jadi ada perbedaan yang signifikan dengan tendensi pada yang terlibat. Artinya antara mahasiswa yang bertitik tolak dari terang injil dan ajaran Gereja dalam memberikan katekese melalui media sosial secara konsisten dan mahasiswa yang tidak bertitik tolak dari terang injil dan ajaran Gereja dalam 
memberikan katekese melalui media sosial secara konsisten terdapat perbedaan yang signifikan dengan tendensi pada yang terlibat karena nilai A lebih besar dari nilai B.

Dari hasil penelitian tentang mahasiswa yang pernah menerima katekese melalui media sosial kemudian membicarakan bersama rekan sejawat diperoleh data berikut. Sebanyak 42 responden $(68,85 \%)$ pernah menerima katekese melalui media sosial kemudian membicarakan bersama rekan sejawat. Sebanyak 19 responden $(31,14 \%)$ tidak pernah menerima katekese melalui media sosial kemudian membicarakan bersama rekan sejawat. Dari hasil pengolahan data menggunakan scoring diperoleh nilai rata-rata 1,68 artinya dalam hal ini mahasiswa sudah baik. Dari pengolahan menggunakan binomial diperoleh nilai z: 2,81 jika dibandingkan dengan nilai tabel maka nilai tersebut lebih rendah dari taraf signifikan 0,05. Jadi ada perbedaan yang signifikan dengan tendensi pada yang terlibat. Artinya antara mahasiswa yang pernah menerima katekese melalui media sosial kemudian membicarakan bersama rekan sejawat dan mahasiswa yang tidak pernah menerima katekese melalui media sosial kemudian membicarakan bersama rekan sejawat terdapat perbedaan yang signifikan dengan tendensi pada yang terlibat karena nilai $\mathrm{A}$ lebih besar dari nilai B.

Dari hasil penelitian tentang mahasiswa yang menerima kritik dan saran dari katekese yang diberikan melalui media sosial dari hasil penelitian diperoleh data berikut. Sebanyak 36 responden $(59,01 \%)$ menerima kritik dan saran dari katekese yang diberikan melalui media sosial. Sebanyak 25 responden (40,98\%) tidak menerima kritik dan saran dari katekese yang diberikan melalui media sosial. Dari hasil pengolahan data menggunakan scoring diperoleh nilai rata-rata 1,59 artinya dalam hal ini mahasiswa sudah baik. Dari pengolahan menggunakan binomial diperoleh nilai z: 1,28 jika dibandingkan dengan nilai tabel maka nilai tersebut lebih rendah dari taraf signifikan 0,05 . Jadi tidak ada perbedaan yang signifikan dengan tendensi pada yang terlibat. Artinya antara mahasiswa yang menerima kritik dan saran dari katekese yang diberikan melalui media sosial dan mahasiswa yang tidak menerima kritik dan saran dari katekese yang diberikan melalui media sosial tidak terdapat perbedaan yang signifikan.

Dari hasil penelitian tentang mahasiswa yang menggunakan media sosial sebagai sarana katekese secara situasional (saat-saat tertentu saja) diperoleh data 
berikut. Sebanyak 55 responden $(90,16 \%)$ menggunakan media sosial sebagai sarana katekese secara situasional (saat-saat tertentu saja). Sebanyak 6 responden $(9,83 \%)$ tidak menggunakan media sosial sebagai sarana katekese secara situasional (saat-saat tertentu saja). Dari hasil pengolahan data menggunakan scoring diperoleh nilai ratarata 1,90 artinya dalam hal ini mahasiswa sudah baik. Dari pengolahan menggunakan binomial diperoleh nilai z: 6,14 jika dibandingkan dengan nilai tabel maka nilai tersebut lebih rendah dari taraf signifikan 0,05 . Jadi ada perbedaan yang signifikan dengan tendensi pada yang terlibat. Artinya antara mahasiswa yang menggunakan media sosial sebagai sarana katekese secara situasional (saat-saat tertentu saja) dan mahasiswa yang tidak menggunakan media sosial sebagai sarana katekese secara situasional (saat-saat tertentu saja) terdapat perbedaan yang signifikan dengan tendensi pada yang terlibat karena nilai A lebih besar dari nilai B.

Dari hasil penelitian tentang mahasiswa yang mengambil materi katekese siap pakai dari sumber lain untuk dibagikan di media sosial diperoleh data berikut. Sebanyak 45 responden $(73,77 \%)$ mengambil materi katekese siap pakai dari sumber lain untuk dibagikan di media sosial. Sebanyak 16 responden (26,22\%) tidak mengambil materi katekese siap pakai dari sumber lain untuk dibagikan di media sosial. Dari hasil pengolahan data menggunakan scoring diperoleh nilai rata-rata 1,73 artinya dalam hal ini mahasiswa sudah baik. Dari pengolahan menggunakan binomial diperoleh nilai z: 3,58 jika dibandingkan dengan nilai tabel maka nilai tersebut lebih rendah dari taraf signifikan 0,05 . Jadi ada perbedaan yang signifikan dengan tendensi pada yang terlibat. Artinya antara mahasiswa yang mengambil materi katekese siap pakai dari sumber lain untuk dibagikan di media sosial dan mahasiswa yang tidak mengambil materi katekese siap pakai dari sumber lain untuk dibagikan di media sosial terdapat perbedaan yang signifikan dengan tendensi pada yang terlibat karena nilai A lebih besar dari nilai B.

Dari hasil penelitian tentang mahasiswa yang memiliki jenis media sosial yang mendukung keterlibatan dalam menggunakan media sosial sebagai sarana katekese diperoleh data berikut. Sebanyak 56 responden $(91,80 \%)$ memiliki jenis media sosial yang digunakan mendukung keterlibatan dalam menggunakan media sosial sebagai sarana katekese. Sebanyak 5 responden $(8,19 \%)$ tidak memiliki jenis media sosial yang mendukung keterlibatan dalam menggunakan media sosial sebagai sarana 
katekese. Dari hasil pengolahan data menggunakan scoring diperoleh nilai rata-rata 1,91 artinya dalam hal ini mahasiswa sudah baik. Dari pengolahan menggunakan binomial diperoleh nilai z: 6,40 jika dibandingkan dengan nilai tabel maka nilai tersebut lebih rendah dari taraf signifikan 0,05. Jadi ada perbedaan yang signifikan dengan tendensi pada yang terlibat.

Penggunaan sosial media untuk sarana katekese oleh milenial yang menjadi mahasiswa di sekolah tinggi agama di Malang Jawa Timur dapat dibahas dengan teori keterlibatan (involvement theory). Teori keterlibatan (involvement theory) banyak dibahas oleh para ahli. Salah satunya yang dikemukakan oleh Sheriff dan Hovland. Penelitian Sheriff dan Hovland yang dilakukan pada tahun 1964 menyebutkan bahwa penerima pesan dengan akses dan intensitas yang tinggi dengan informasi yang tinggi, berkaitan dengan keyakinan dan pengalaman yang telah dialami sebelumnya. ${ }^{28}$

Dalam penelitian ini, mahasiswa yang memiliki jenis media sosial yang mendukung keterlibatan dalam menggunakan media sosial sebagai sarana katekese cukup signifikan dengan tendensi pada yang terlibat. Menurut Ching-Yuan Huang, Chia-Jung Chou, dan Pei-Ching Lin, teori keterlibatan (involvement theory) dalam digunakan untuk mengetahui, dan mengukur perilaku sosial yang dilakukan yang dilakukan. ${ }^{29}$ Dalam hal keterlibatan mahasiswa di sekolah tinggi agama di malang pada kegiatan katekese dengan menggunakan media sosial, ditemukan relevansi dengan teori keterlibatan yang dilakukan oleh Huang dan kawan-kawan. Menggunakan media sosial untuk keperluan katekese adalah perilaku yang biasa dipraktikkan. Penggunaan media sosial sudah menjadi kebiasaan. Dalam penelitian yang dilakukan oleh Rebecca Dolan, dan kawan-kawan, media sosial memiliki daya tarik rasional yang membuat perilaku penggunanya untuk aktif di dalam kegiatan yang melibatkan media sosial sebagai sarana. Media sosial memiliki efek unggul dalam memfasilitasi penggunanya untuk terlibat aktif. ${ }^{30}$ Mahasiswa yang menggunakan media sosial dalam kegiatan katekese, mayoritas terlibat aktif di dalam kegiatan katekese, daripada yang tidak aktif. Dalam hal ini, media sosial memiliki fungsi untuk mendorong pada mahasiswa untuk aktif di katekese.Houston dan Rothschild pada tahun 1980 melakukan penelitian yang menggunakan teori keterlibatan (involvement theory). Menurut Houston dan Rothschild, keterlibatan dapat dibagi pada dua, keterlibatan aktif (enduring involvement) dan keterlibatan pasif (situational 
involvement). Keterlibatan aktif (enduring involvement) merupakan hubungan jangka panjang antara individu dengan objek yang menjadi perhatian. Keterlibatan aktif terjadi ketika subjek menunjukkan minat yang tinggi dan konsisten terhadap suatu hal dan sering kali menghabiskan waktu untuk memikirkan tentang hal tersebut. Hubungan ini terjadi jangka panjang antara individu dengan objek yang menjadi perhatian, maka keterlibatan abadi bergantung pada pengalaman masa lalu subjek dengan objek tersebut dan nilai-nilai yang kuat yang terkait dengan objek tersebut. ${ }^{31}$

Mahasiswa sekolah tinggi agama di Malang Jawa Timur memiliki keterlibatan aktif (enduring involvement). Hal tersebut diketahui dari minat dan konsistensi dalam menggunakan media sosial sebagai sarana katekese. Termasuk tingkat konsistensi dalam membuat persiapan katekese yang dipublikasikan di dalam media sosial dan dibagikan kepada banyak orang, menjadi acuan tingkat keterlibatan para mahasiswa. Keterlibatan aktif muncul bila kegiatan katekese menjadi salah satu kegiatan yang menjadi kewajiban sekaligus kebutuhan bagi mahasiswa. Kebutuhan katekese menguat saat para mahasiswa menghabiskan waktu, tenaga, dan pikirannya untuk fokus pada kegiatan katekese. Mahasiswa memiliki minat dan ketertarikan yang tinggi terhadap penggunaan media sosial sebagai sarana katekese. Keterlibatan aktif (enduring involvement) diperoleh dari persepsi bahwa objek berhubungan dengan nilai yang dipegang, sedangkan situasional involvement ketika subjek mengetahui resiko pada situasi tertentu. ${ }^{32}$

Involvement merupakan tingkat ketertarikan seseorang terhadap objek. Selain itu involvement juga berkaitan dengan tingkat atau keadaan dimana hasrat, ketertarikan atau dorongan yang muncul karena pengaruh stimulus atau situasi. ${ }^{33}$ Adapun keterlibatan pasif (situational involvement) terjadi hanya dalam waktu yang sementara dan diasosiasikan dengan situasi yang spesifik serta tingkat kepedulian atau ketertarikan terhadap sebuah objek yang dipicu oleh situasi tertentu dan bersifat sementara. ${ }^{34}$ Ada juga keterlibatan pasif mahasiswa sekolah tinggi agama di Malang Jawa Timur terhadap penggunaan media sosial sebagai sarana katekese. Ada mahasiswa yang terlibat dalam kegiatan katekese hanya bersifat pasif/ situasional yang diakibatkan karena kondisi yang menuntut mahasiswa untuk melakukan hal tersebut. Seperti adanya mahasiswa yang melakukan katekese hanya pada saat mengerjakan tugas yang diberikan berkaitan dengan mata kuliah tertentu. Ada pula 
yang keikutsertaan dalam menggunakan media sosial hanya sebagai sarana pendukung pada saat tertentu saja.

Penggunaan teori keterlibatan (involvement theory) juga pernah dilakukan oleh Krugman pada tahun 1965. Krugman melihat hubungan antara involvement dengan pengalaman mengakses informasi dan pengaruh dari media masa terhadap keterlibatan (involvement). Terkadang objek tidak selalu terlibat di dalam perilaku yang diiginkan oleh pemberi pesan. Objek komunikasi yang terlibat dengan pemberi pesan akan mengubah sikap sesuai dengan yang diinginkan pemberi pesan. ${ }^{35}$ Menurut Krugmen keterlibatan ditemukan pada stimulus yang diberikan melalui media seperti televisi pada penonton yang berpikir secara spontan pada kehidupan mereka. ${ }^{36}$ Seseorang mengalami perubahan secara bertahap di dalam keterlibatannya terhadap pesan yang diterimanya. Semakin berulang menerima pesan, maka semakin cepat berubah. ${ }^{37}$

Mahasiswa sebagai penerima pesan katakese mengalami perubahan pada perilaku mereka seiring dengan seringnya mereka menerima pesan yang diperoleh melalui sosial media. Untuk selanjutnya mereka juga mengirimkan pesan yang diterima di media sosial kepada orang lain untuk menyampaikan pesan keimanan dan rohani. Sehingga media sosial secara nyata membentuk perilaku para katesis, salah satunya disebabkan oleh aspek media sosial yang mudah dan fleksibel.

Media sosial meningkatkan kesukaan mahasiswa terhadap materi yang ada di dalam sosial media saat mahasiswa melakukan aktivitas dan kegiatan pembelajaran. Tidak hanya karena layanan yang memudahkan untuk diakses dan dicerna, namun juga karena konten dan isinya yang lebih bervariasi. Sehingga apa yang dinikmati tidak monoton hanya yang disampaikan oleh pemberi pesan. ${ }^{38}$

\section{KESIMPULAN}

Mahasiswa di sekolah tinggi agama di Malang, Jawa Timur menggunakan media sosial sebagai sarana katekese. Keterlibatan mahasiswa di dalam menggunakan media sosial sebagai sarana katekese berjalan dengan baik dengan skor 1,72. Berdasarkan hasil pengolahan data menggunakan uji binomial diperoleh nilai $z=4,05$. Jika dibandingkan dengan nilai tabel maka nilai tersebut lebih rendah dari taraf signifikan 0,05 artinya ada perbedaan antara keterlibatan mahasiswa yang satu dengan 
yang lain dalam menggunakan media sosial sebagai sarana katekese. Maka Ho ditolak dan Ha diterima.

Mahasiswa sekolah tinggi agama di Malang Jawa Timur memiliki keterlibatan aktif (enduring involvement). Hal tersebut diketahui dari minat dan konsistensi dalam menggunakan media sosial sebagai sarana katekese. Termasuk tingkat konsistensi dalam membuat persiapan katekese yang dipublikasikan di dalam media sosial dan dibagikan kepada banyak orang, menjadi acuan tingkat keterlibatan para mahasiswa. Ada juga keterlibatan pasif mahasiswa sekolah tinggi agama di Malang Jawa Timur terhadap penggunaan media sosial sebagai sarana katekese. Ada mahasiswa yang terlibat dalam kegiatan katekese hanya bersifat pasif/ situasional yang diakibatkan karena kondisi yang menuntut mahasiswa untuk melakukan hal tersebut. Seperti adanya mahasiswa yang melakukan menggunakan media sosial hanya pada saat mengerjakan tugas yang diberikan berkaitan dengan mata kuliah tertentu.

\section{Endnotes:}

\footnotetext{
${ }^{1}$ Mohammad Hidayaturrahman, "Corporate Social Responsibility Strategi Komunikasi Perusahaan Migas,” Jurnal Nomosleca 3, no. 24 (2017): https://doi.org/https://doi.org/10.26905/nomosleca.v3i2.2036.

2 Sebastián Valenzuela, Martina Piña, and Josefina Ramírez, "Behavioral Effects of Framing on Social Media Users: How Conflict, Economic, Human Interest, and Morality Frames Drive News Sharing," Journal of Communication 67, no. 5 (2017): 803-26, https://doi.org/10.1111/jcom.12325.

3 Anne Vermeulen, Heidi Vandebosch, and Wannes Heirman, "\#Smiling, \#Venting, or Both? Adolescents' Social Sharing of Emotions on Social Media," Computers in Human Behavior, 2018, 2 34, https://doi.org/10.1016/j.chb.2018.02.022.

${ }^{4}$ W Akram and R Kumar, "A Study on Positive and Negative Effects of Social Media on Society," International Journal of Computer Sciences and Engineering 5, no. 10 (2017): 347-54, https://doi.org/10.26438/ijcse/v5i10.351354.

${ }^{5}$ Phil Longstreet and Stoney Brooks, "Technology in Society Life Satisfaction : A Key to Managing Internet \& Social Media Addiction," Technology in Society 50 (2017): 73-77, https://doi.org/10.1016/j.techsoc.2017.05.003.

6 Matt Carlson, "Facebook in the News," Digital Journalism 0811, no. March (2017): 1-17, https://doi.org/10.1080/21670811.2017.1298044.

${ }^{7}$ Asuncion Esteve, "The Business of Personal Data: Google, Facebook, and Privacy Issues in the EU and the USA," International Data Privacy Law 7, no. 1 (2017): 36-47.

${ }^{8}$ Baobao Zhang et al., "Quota Sampling Using Facebook Advertisements," Political Science Research and Methods, 2018, 1-7, https://doi.org/10.1017/psrm.2018.49.

${ }^{9}$ Evangelos Karapanos, Pedro Teixeira, and Ruben Gouveia, "Need Fulfillment and Experiences on Social Media: A Case on Facebook and WhatsApp," Computers in Human Behavior 55 (2016): 88897, https://doi.org/10.1016/j.chb.2015.10.015.

${ }^{10}$ Pamela E. Walck, "Twitter: Social Communication in the Twitter Age," International Journal of Interactive Communication Systems and Technologies 3, no. 2 (2013): 66-69, https://doi.org/10.1080/1369118x.2019.1620824.
} 


\section{MEDIA SOSIAL SEBAGAI SARANA KATEKESE MAHASISWA \\ DI MALANG, JAWA TIMUR}

11 Nita Siti Mudawamah, "Perilaku Pengguna Internet: Studi Kasus Pada Mahasiswa Jurusan Perpustakaan Dan Ilmu Informasi Uin Maulana Malik Ibrahim," BIBLIOTIKA: Jurnal Kajian Perpustakaan Dan Informasi 4, no. 1 (2020): 107-13.

12 Aceng Abdullah and Lilis Puspitasari, "Media Televisi Di Era Internet," ProTVF 2, no. 1 (2018): 101, https://doi.org/10.24198/ptvf.v2i1.19880.

${ }^{13}$ Kadhung Prayoga, "Pemanfaatan Sosial Media Dalam Penyuluhan Pertanian Dan Perikanan Di Indonesia," Agriekonomika 6, no. 1 (2017), https://doi.org/10.21107/agriekonomika.v6i1.2680.

14 Miftahulkhairah Anwar, "Impoliteness in Indonesian Language on Facebook as A Representation of Cultural Blindness," Journal of Multicultural Education 5, no. 1 (2019): 88-91.

15 Lucy Pujasari Supratman, "Penggunaan Media Sosial Oleh Digital Native," Jurnal ILMU KOMUNIKASI 15, no. 1 (2018): 47-60.

${ }^{16}$ Minchatus Salwa and Nani Febrianti, ““FFleksibel Dan Mudah“ Pembelajaran Bahasa Terkini Melalui Media Sosial," in Seminar Nasional Pembelajaran Bahasa Dan Sastra (SELASAR) 4 (Malang: Universitas Negeri Malang, 2020), 165-71.

${ }^{17}$ Jodi Dworkin, Jessie H Rudi, and Heather Hessel, "The State of Family Research and Social Media," Journal of Family Theory and Review, 2018, 1-18, https://doi.org/10.1111/jftr.12295.

${ }^{18}$ Philip Pond and Jeff Lewis, "Riots and Twitter: Connective Politics, Social Media and Framing Discourses in the Digital Public Sphere," Information, Communication \& Society 0, no. 0 (2017): 1-19, https://doi.org/10.1080/1369118X.2017.1366539.

19 Jamie Bering et al., "Deferred Personal Life Decisions of Women Physicians," JOURNAL OF WOMEN'S HEALTH 00, no. 00 (2018): 1-6, https://doi.org/10.1089/jwh.2016.6315.

${ }^{20}$ James Meneghello et al., "Unlocking Social Media and User Generated Content as a Data Source for Knowledge Management," International Journal of Knowledge Management 16, no. 1 (2020): 101-22, https://doi.org/10.4018/IJKM.2020010105.

${ }^{21}$ Joseph Kahne and Benjamin Bowyer, "The Political Significance of Social Media Activity and Social Networks and Social Networks," Political Communication 00, no. 00 (2018): 1-24, https://doi.org/10.1080/10584609.2018.1426662.

${ }^{22}$ Reto Felix, Philipp A Rauschnabel, and Chris Hinsch, "Elements of Strategic Social Media Marketing: A Holistic Framework," Journal of Business Research, 2016, 1-9, https://doi.org/10.1016/j.jbusres.2016.05.001.

${ }^{23}$ Alexandra Vițelar, "Like Me: Generation Z and the Use of Social Media for Personal Branding," Management Dynamics in the Knowledge Economy 7, no. 2 (2019): 257-68, https://doi.org/10.25019/MDKE/7.2.07.

${ }^{24}$ Yeremias Banusu, "Mengkomunikasikan Diri Allah Terhadap Ciptaan Sebagai Dasar Pewartaan Kaum Awam," Fides et Ratio Jurnal Teologi Kontestual 4, no. 2 (2018): 19-50.

${ }^{25}$ Robert Pius Manik, Adi Saptowidodo, and Antonius Sad Budianto, Pembaharuan Gereja Melalui Katekese: Superfisialisme, Aktivisme, Fundamentalisme Dan Spiritualisme Tantangan Katekese Dewasa Ini, ed. Robert Pius Manik, Adi Saptowidodo, and Antonius Sad Budianto (Malang: STFT Widya Sasana, 2018).

${ }^{26}$ Kanisius Komsiah Dadi, "Kahoot Sebagai Media Pendukung Dalam Berkatese Dengan Berbasis Teknologi Digital,” Jurnal Pendiidikan Dan Kebudayaan Missio 11, no. 2 (2019): 214-30.

${ }^{27}$ Paskalis Edwin, I Nyoman Paska, and Laurensius Laka, "Pengaruh Lingkungan Sosial Terhadap SelfRegulated Learning Siswa,” SAPA Jurnal Kateketik Dan Pastoral 5, no. 2 (2020): 39-54.

${ }^{28}$ Wendy Wood, Carl A. Kallgren, and Rebecca Mueller Preisler, "Access to Attitude-Relevant Information in Memory as a Determinant of Persuasion: The Role of Message Attributes," Journal of Experimental Social Psychology 21, no. 1 (1985): 73-85, https://doi.org/10.1016/0022-1031(85)900071.

${ }^{29}$ Ching Yuan Huang, Chia Jung Chou, and Pei Ching Lin, "Involvement Theory in Constructing Bloggers' Intention to Purchase Travel Products," Tourism Management 31, no. 4 (2010): 513-26, https://doi.org/10.1016/j.tourman.2009.06.003.

${ }^{30}$ Rebecca Dolan et al., "Social Media Engagement Behavior: A Framework for Engaging Customers through Social Media Content," European Journal of Marketing 53, no. 10 (2019): 2213-43, https://doi.org/10.1108/EJM-03-2017-0182.

${ }^{31}$ Michael L. Rothschild and Michael J. Houston, "Individual Differences in Voting Behavior: Further Investigations of Involvement," Advances in Consumer Research 7 (1980): 655-58. 


\footnotetext{
${ }^{32}$ Mark E Havitz and Roger C Mannell, "Enduring Involvement, Situational Involvement, and Flow in Leisure and Non-Leisure Activities," Journal of Leisure Research 37, no. 2 (2005): 152-77, https://doi.org/10.1080/00222216.2005.11950048.

${ }^{33} \mathrm{~N}$ Mcintyre, "The Personal Meaning of Participation : Enduring Involvement The Personal Meaning of Participation:," Journal of Leisure Research 21, no. 2 (1989): 167-79, https://doi.org/10.1080/00222216.1989.11969797.

34 Marsha L Richins, Peter H Bloch, and Edward F Mcquarrie, "How Enduring and Situational Involvement Combine to Create Involvement Responses," Journal Of Consumer Psychology 1, no. 2 (1992): 143-53.

${ }^{35}$ Herbert E. Krugman, “The Impact of Television Advertising: Learning without Involvement," Public Opinion Quarterly 29, no. 3 (1965): 349-56, https://doi.org/10.1086/267335.

${ }^{36}$ Herbert E. Krugman, "Brain Wave Measures of Media Involvement," Journal of Advertising Research 11, no. 1 (1971): 3-9, https://doi.org/10.4135/9781452231501.n13.

${ }^{37}$ Herbert E Krugman, “The Measurement of Advertising Involvement,” Public Opinion Quarterly 30, no. 4 (1966): 583-96.

${ }^{38}$ Meyliana, Achmad Nizar Hidayanto, and Eko Kuswardono Budiardjo, "Evaluation of Social Media Channel Preference for Student Engagement Improvement in Universities Using Entropy and Topsis Method," Journal of Industrial Engineering and Management 8, no. 5 (2015): 1676-97, https://doi.org/10.3926/jiem.1652.
}

\section{DAFTAR PUSTAKA}

Abdullah, Aceng, and Lilis Puspitasari. "Media Televisi Di Era Internet." ProTVF 2, no. 1 (2018): 101. https://doi.org/10.24198/ptvf.v2i1.19880.

Akram, W, and R Kumar. "A Study on Positive and Negative Effects of Social Media on Society.” International Journal of Computer Sciences and Engineering 5, no. 10 (2017): 347-54. https://doi.org/10.26438/ijcse/v5i10.351354.

Anwar, Miftahulkhairah. "Impoliteness in Indonesian Language on Facebook as A Representation of Cultural Blindness." Journal of Multicultural Education 5, no. 1 (2019): 88-91.

Banusu, Yeremias. "Mengkomunikasikan Diri Allah Terhadap Ciptaan Sebagai Dasar Pewartaan Kaum Awam.” Fides et Ratio Jurnal Teologi Kontestual 4, no. 2 (2018): 19-50.

Bering, Jamie, Lacey Pflibsen, Cassie Eno, and Priya Radhakrishnan. "Deferred Personal Life Decisions of Women Physicians." JOURNAL OF WOMEN'S HEALTH 00, no. 00 (2018): 1-6. https://doi.org/10.1089/jwh.2016.6315.

Carlson, Matt. "Facebook in the News." Digital Journalism 0811, no. March (2017): 1-17. https://doi.org/10.1080/21670811.2017.1298044. 
Dadi, Kanisius Komsiah. "Kahoot Sebagai Media Pendukung Dalam Berkatese Dengan Berbasis Teknologi Digital.” Jurnal Pendiidikan Dan Kebudayaan Missio 11, no. 2 (2019): 214-30.

Dolan, Rebecca, Jodie Conduit, Catherine Frethey-Bentham, John Fahy, and Steve Goodman. "Social Media Engagement Behavior: A Framework for Engaging Customers through Social Media Content." European Journal of Marketing 53, no. 10 (2019): 2213-43. https://doi.org/10.1108/EJM-03-2017-0182.

Dworkin, Jodi, Jessie H Rudi, and Heather Hessel. "The State of Family Research and Social Media." Journal of Family Theory and Review, 2018, 1-18. https://doi.org/10.1111/jftr.12295.

Edwin, Paskalis, I Nyoman Paska, and Laurensius Laka. "Pengaruh Lingkungan Sosial Terhadap Self-Regulated Learning Siswa." SAPA Jurnal Kateketik Dan Pastoral 5, no. 2 (2020): 39-54.

Esteve, Asuncion. "The Business of Personal Data: Google, Facebook, and Privacy Issues in the EU and the USA." International Data Privacy Law 7, no. 1 (2017): 36-47.

Felix, Reto, Philipp A Rauschnabel, and Chris Hinsch. "Elements of Strategic Social Media Marketing: A Holistic Framework.” Journal of Business Research, 2016, 1-9. https://doi.org/10.1016/j.jbusres.2016.05.001.

Havitz, Mark E, and Roger C Mannell. "Enduring Involvement, Situational Involvement, and Flow in Leisure and Non-Leisure Activities." Journal of $\begin{array}{lllll}\text { Leisure } & \text { Research } & \text { 37, } & \text { (2005): }\end{array}$ https://doi.org/10.1080/00222216.2005.11950048.

Hidayaturrahman, Mohammad. "Corporate Social Responsibility Strategi Komunikasi Perusahaan Migas." Jurnal Nomosleca 3, no. 2 (2017): 614-24. https://doi.org/https://doi.org/10.26905/nomosleca.v3i2.2036.

Huang, Ching Yuan, Chia Jung Chou, and Pei Ching Lin. "Involvement Theory in Constructing Bloggers' Intention to Purchase Travel Products." Tourism Management 31, no. 4 (2010): 513-26. https://doi.org/10.1016/j.tourman.2009.06.003.

Kahne, Joseph, and Benjamin Bowyer. "The Political Significance of Social Media 
Activity and Social Networks and Social Networks." Political Communication 00, no. 00 (2018): 1-24. https://doi.org/10.1080/10584609.2018.1426662.

Karapanos, Evangelos, Pedro Teixeira, and Ruben Gouveia. "Need Fulfillment and Experiences on Social Media: A Case on Facebook and WhatsApp." Computers in Human Behavior 55 (2016): 888-97. https://doi.org/10.1016/j.chb.2015.10.015.

Krugman, Herbert E. "Brain Wave Measures of Media Involvement." Journal of Advertising Research 11, no. 1 (1971): 3-9. https://doi.org/10.4135/9781452231501.n13.

—. "The Impact of Television Advertising: Learning without Involvement." Public Opinion Quarterly 29, no. 3 (1965): 349-56. https://doi.org/10.1086/267335.

Krugman, Herbert E. "The Measurement of Advertising Involvement." Public Opinion Quarterly 30, no. 4 (1966): 583-96.

Longstreet, Phil, and Stoney Brooks. "Technology in Society Life Satisfaction: A Key to Managing Internet \& Social Media Addiction." Technology in Society 50 (2017): 73-77. https://doi.org/10.1016/j.techsoc.2017.05.003.

Manik, Robert Pius, Adi Saptowidodo, and Antonius Sad Budianto. Pembaharuan Gereja Melalui Katekese: Superfisialisme, Aktivisme, Fundamentalisme Dan Spiritualisme Tantangan Katekese Dewasa Ini. Edited by Robert Pius Manik, Adi Saptowidodo, and Antonius Sad Budianto. Malang: STFT Widya Sasana, 2018.

Mcintyre, N. “The Personal Meaning of Participation: Enduring Involvement The Personal Meaning of Participation :" Journal of Leisure Research 21, no. 2 (1989): 167-79. https://doi.org/10.1080/00222216.1989.11969797.

Meneghello, James, Nik Thompson, Kevin Lee, Kok Wai Wong, and Bilal Abu-Salih. "Unlocking Social Media and User Generated Content as a Data Source for Knowledge Management." International Journal of Knowledge Management 16, no. 1 (2020): 101-22. https://doi.org/10.4018/IJKM.2020010105.

Meyliana, Achmad Nizar Hidayanto, and Eko Kuswardono Budiardjo. "Evaluation of Social Media Channel Preference for Student Engagement Improvement in 
Universities Using Entropy and Topsis Method." Journal of Industrial Engineering and Management 8, no. 5 (2015): 1676-97. https://doi.org/10.3926/jiem.1652.

Mudawamah, Nita Siti. "Perilaku Pengguna Internet: Studi Kasus Pada Mahasiswa Jurusan Perpustakaan Dan Ilmu Informasi Uin Maulana Malik Ibrahim.” BIBLIOTIKA : Jurnal Kajian Perpustakaan Dan Informasi 4, no. 1 (2020): 107-13.

Pond, Philip, and Jeff Lewis. "Riots and Twitter: Connective Politics, Social Media and Framing Discourses in the Digital Public Sphere." Information, Communication \& Society 0 , no. 0 (2017): 1-19. https://doi.org/10.1080/1369118X.2017.1366539.

Prayoga, Kadhung. "Pemanfaatan Sosial Media Dalam Penyuluhan Pertanian Dan Perikanan Di Indonesia." Agriekonomika 6, no. 1 (2017). https://doi.org/10.21107/agriekonomika.v6i1.2680.

Richins, Marsha L, Peter H Bloch, and Edward F Mcquarrie. "How Enduring and Situational Involvement Combine to Create Involvement Responses.” Journal Of Consumer Psychology 1, no. 2 (1992): 143-53.

Rothschild, Michael L., and Michael J. Houston. "Individual Differences in Voting Behavior: Further Investigations of Involvement." Advances in Consumer Research 7 (1980): 655-58.

Salwa, Minchatus, and Nani Febrianti. ““"Fleksibel Dan Mudah“ Pembelajaran Bahasa Terkini Melalui Media Sosial.” In Seminar Nasional Pembelajaran Bahasa Dan Sastra (SELASAR) 4, 165-71. Malang: Universitas Negeri Malang, 2020.

Supratman, Lucy Pujasari. "Penggunaan Media Sosial Oleh Digital Native.” Jurnal ILMU KOMUNIKASI 15, no. 1 (2018): 47-60.

Valenzuela, Sebastián, Martina Piña, and Josefina Ramírez. "Behavioral Effects of Framing on Social Media Users: How Conflict, Economic, Human Interest, and Morality Frames Drive News Sharing.” Journal of Communication 67, no. 5 (2017): 803-26. https://doi.org/10.1111/jcom.12325.

Vermeulen, Anne, Heidi Vandebosch, and Wannes Heirman. “\#Smiling, \#Venting, or

Both? Adolescents' Social Sharing of Emotions on Social Media." Computers 
in Human Behavior, 2018, 2-34. https://doi.org/10.1016/j.chb.2018.02.022.

Vițelar, Alexandra. "Like Me: Generation Z and the Use of Social Media for Personal Branding." Management Dynamics in the Knowledge Economy 7, no. 2 (2019): 257-68. https://doi.org/10.25019/MDKE/7.2.07.

Walck, Pamela E. "Twitter: Social Communication in the Twitter Age." International Journal of Interactive Communication Systems and Technologies 3, no. 2 (2013): 66-69. https://doi.org/10.1080/1369118x.2019.1620824.

Wood, Wendy, Carl A. Kallgren, and Rebecca Mueller Preisler. "Access to AttitudeRelevant Information in Memory as a Determinant of Persuasion: The Role of Message Attributes.” Journal of Experimental Social Psychology 21, no. 1 (1985): 73-85. https://doi.org/10.1016/0022-1031(85)90007-1.

Zhang, Baobao, Matto Mildenberger, Peter D Howe, Jennifer Marlon, Seth A Rosenthal, and Anthony Leiserowitz. "Quota Sampling Using Facebook Advertisements." Political Science Research and Methods, 2018, 1-7. https://doi.org/10.1017/psrm.2018.49. 